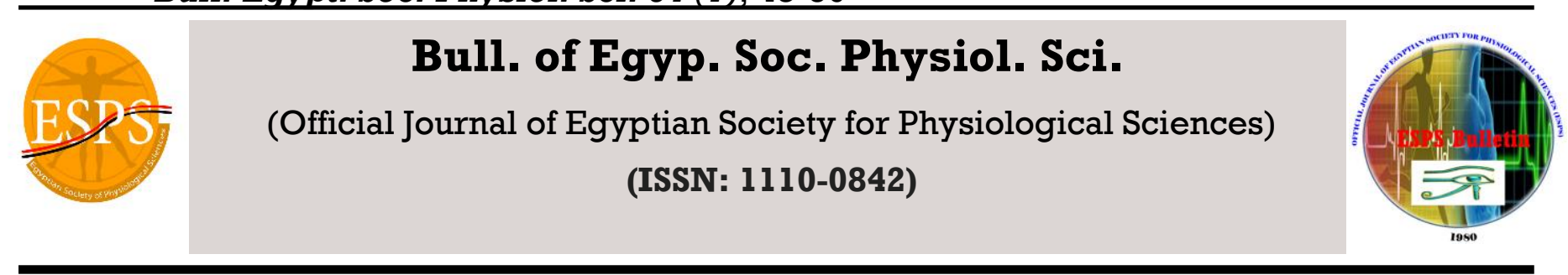

\title{
Effect of Systemic Ghrelin Administration on Experimental Myocardial Infarction Induced by Isoproterenol in Rats
}

\section{Abeer A. Abozeid ${ }^{1}$ Ghada M. Abou Fard ${ }^{1}$ and Noha M. Shafik ${ }^{2}$}

\author{
Departments of ${ }^{1}$ Physiology, Biochemistry ${ }^{2}$,Faculty of Medicine, Tanta University, Tanta, Egypt.
}

Received: Feb 10, 2014

Accepted: March 14, 2014

Available online: April 27,2014

\section{Keywords}

Isoproterenol

Myocardial infarction

Creatine kinase-MB

Paraoxonase

\begin{abstract}
Objective: Is to investigate the possible effects of ghrelin administration on isoproterenol (ISO)induced myocardial infarction (MI) in albino rats of local strain. Methods: 30 adult male albino rats were divided into 3 groups, each consisted of 10 rats. Group I: received saline as a control group. Group II: ISO injected subcutaneously to rats $(100 \mathrm{mg} / \mathrm{kg})$ at an interval of $24 \mathrm{~h}$ for 2 days. Group III: rats were pretreated with ghrelin $(150 \mu \mathrm{g} / \mathrm{kg}$, s.c.) for 15 days and at the 14 th and 15 th days received ISO as in group II. Levels of serum cardiac enzymes (CK, CK-MB fraction and LDH), lipid profiles and plasma TNF- $\alpha$ and IL-6 were evaluated. Specimens from heart were obtained to measure the levels of TNF- $\alpha$, IL-6, lipid peroxidation products (MDA,GSH)and endogenous antioxidants enzymes activities (CAT,SOD,PON1). Results: ISO- treated rats showed significant increase in the activities of serum cardiac enzymes, plasma and cardiac tissues TNF- $\alpha$ and IL-6, as well as in heart tissues level of MDA and GSH and in serum cholesterol, triglycerides, LDL-cholesterol, VLDL .On the other hand there are significant decrease in tissues SOD and PON1 enzyme activities and serum HDL-cholesterol when these results were compared to control rats. Pretreatment with ghrelin significantly attenuated these changes as compared to ISO treated rats (group I). Conclusions: This finding demonstrated that ghrelin may be considered as promising new therapies for MI
\end{abstract}

Corresponding author: Abeer A. Abozeid, M.D., Department of Medical Physiology, Faculty of Medicine, Tanta University, Tanta, Egypt Email: abeer.abozeid@yahoo.com .Mob.: +201002085005 


\section{INTORDUCTION}

Myocardial infarction (MI) is one of major public health problem in the world. MI is a condition of acute myocardial necrosis due to imbalance between coronary blood flow and myocardial needs, and it is followed by antioxidant deficit as well as increased myocardial oxidative stress. ${ }^{1}$ Experimental and clinical studies have shown that infarct size of myocardial necrosis can be limited by development of endogenous antioxidant enzymes and suppression of free radical generation. ${ }^{2}$ Isoproterenol (ISO) a synthetic non-selective $\beta$-adrenoceptor agonist, has been reported to produce MI in large doses; upon autooxidation (ISO) generates highly cytotoxic free radicals known to stimulate the peroxidation of membrane phospholipids causing severe damage to the myocardial membrane. Hence, it is used as a model to produce MI in rats'. Myocardial infarction of isoproterenol-treated rats has been found to be similar to human $\mathrm{MI}$ in pathophysiological and morphological changes. $^{3}$

Ghrelin produced primarily by the X/A-like enteroendocrine cells of the stomach is synthesized as a preprohormone and then proteolytically processed to yield a 28amino acid peptide. Ghrelin is an endogenous ligand for the growth hormone secretagogue receptor. This peptide was originally reported to induce growth hormone release; large evidence, however, has indicated many other physiological activities of ghrelin, including regulation of food intake and energy balance, as well as of lipid and glucose metabolism. ${ }^{4}$ Within cardiovascular system, two GHS-R subtypes, GHS-R1a and GHS-R1b, are present in the heart and in the blood vessels. Stimulation of GHSR prevents cardiac damage after ischemia/reperfusion in hypophysectomized rats. ${ }^{5}$ However, the mechanisms of influence of ghrelin on the cardiovascular system is not fully understood. ${ }^{6}$ Therefore, the aim of this study was to evaluate the effect of ghrelin on ISOinduced myocardial damage in Wistar rats.

\section{MATERIALS AND METHODS}

This study was carried out on 30 white Male adult albino rats (Wistar strain, their weight ranged between 150-200 g, during the study the animals were kept in wire mesh cages the animals were fed standard pellet diet with ad libitum access to water. The room temperature was about $22-24^{\circ} \mathrm{C}$ and the animals were exposed to 12:12 hours light dark cycles. Standard pellet diet was purchased from El-Gomhoria Company, Cairo, Egypt. Our work was carried out in accordance with the guidelines of the Ethical Committee of Medical Research of Faculty of Medicine Tanta University. 
The animals were randomly divided into three equal groups (each was 10 rats):

Group I; control group was given $0.9 \%$ $\mathrm{NaCl}$.

Group II ;isoproterenol-treated group (ISO) was dissolved in normal saline and injected subcutaneously to rats $(100 \mathrm{mg} / \mathrm{kg})$ at an interval of $24 \mathrm{~h}$ for 2 days to induce experimental myocardial infarction. ${ }^{7}$ Animals were sacrificed $24 \mathrm{~h}$ after the second dose of ISO.

Group III; rats were pretreated with ghrelin $(150 \mu \mathrm{g} / \mathrm{kg}$, s.c.) for 15 days and at the 14 and 15 days received isoproterenol $100 \mathrm{mg} / \mathrm{kg}$ s.c. as in group 2.

\section{collection of blood samples}

Twenty four hours after the second dose of ISO, rats of all the groups were anesthetized and sacrificed by cervical decapitation and blood was collected in two tubes, one with anticoagulant (ethylene diamine tetra acetic acid) for plasma separation, and another without anticoagulant for serum separation. Both the plasma and serum were separated from each sample and used for the biochemical analysis.

\section{Biochemical assay in blood}

The activities of creatine kinase $(\mathrm{CK})^{8}$ creatine kinase-MB fraction $(\mathrm{CK}-\mathrm{MB})^{9}$ and serum lactate dehydrogenase $(\mathrm{LDH})^{10}$ were estimated in the serum. Also, lipid profile including; total cholesterol ${ }^{11}$, triglycerides $^{12}$, LDL-cholesterol, $\mathrm{VLDL}^{13}$, and HDL- cholesterol. ${ }^{14}$ The plasma levels of TNF- $\alpha$ and IL-6 were determined with commercially available enzyme-linked immunosorbent assay (ELISA) kits (R\&D Systems).

\section{Biochemical assay in cardiac tissues}

Thorax was opened and heart was harvested, washed in ice-cold saline stored at- $18^{\circ} \mathrm{C}$ for biochemical estimations of cardiac lipid peroxides (MDA), reduced glutathione (GSH), superoxide dismutase (SOD), catalase (CAT) and tissues PON1 enzyme activity. The levels of TNF- $\alpha$ and IL-6 in the myocardial tissue homogenates were determined with commercially available enzyme-linked immunosorbent assay (ELISA) kits (R\&D Systems). Protein content in tissue homogenate was measured according to the method of Lowry et al. ${ }^{15}$ Determination of tissues catalase (CAT) enzyme activity was assayed by the method of Sinha. ${ }^{16}$ MDA, an end product of lipid peroxidation was estimated by the method of Okhawa et $a l .{ }^{17}$ Tissue GSH levels was estimated by the method of Sedlack and Lindsay ${ }^{18}$ and the activity of tissue superoxide dismutase was assayed by the method of Kakkar et al ${ }^{19}$ and tissues PON1 enzyme activity. ${ }^{20}$

\section{Statistical analysis}

Statistical analysis was done using the SPSS software package version 18.0. Statistical analysis was done to obtain the 
mean, the standard deviation and Student $(\mathrm{t})$ test which was used to compare between two groups, where the probability " $p$ " value was significant if $\leq 0.05$.

\section{RESULTS}

The activities of serum CK, CK-MB, and LDH in normal and experimental rats were expressed in figure (1). ISO- treated rats showed significant $(P<0.05)$ increase in the activities of $\mathrm{CK}, \mathrm{CK}-\mathrm{MB}$, and $\mathrm{LDH}$ in the serum when compared to control rats. Pretreatment with ghrelin reduced the levels of these enzymes in the serum when compared to ISO-induced myocardial infracted rats.

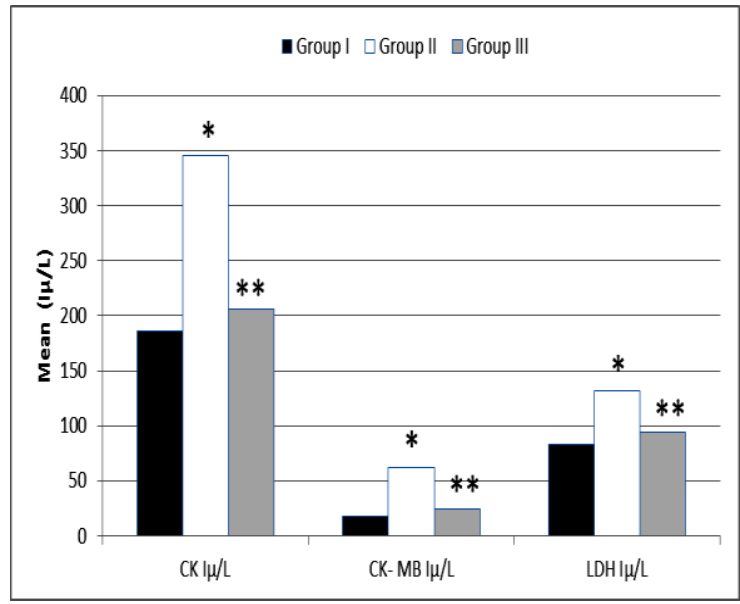

Fig. (1): Effect of ghrelin on cardiac enzymes serum. * denotes significant differences group II vs. group I, ** denotes significant differences group III vs. group II

Levels of plasma and cardiac tissues TNF- $\alpha$ and IL-6 in normal and experimental rats were studied in figures ( $2 a, b$ and $3 a, b)$. ISOtreated rats showed significant $(P<0.05)$ increase in the levels of plasma and cardiac tissues TNF- $\alpha$ and IL- 6 when compared to control rats. Pretreatment with ghrelin reduced the levels of these inflammatory markers in the plasma, and cardiac tissues when compared to ISO alone treated rats.

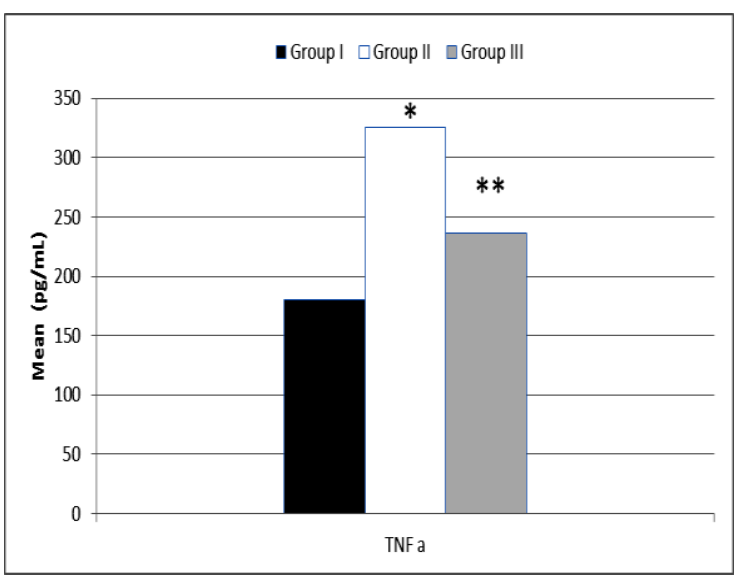

Fig. (2a): Effect of ghrelin on levels of TNF $\alpha$ in plasma.* denotes significant differences group II vs. group I, ** denotes significant differences group III vs. group II

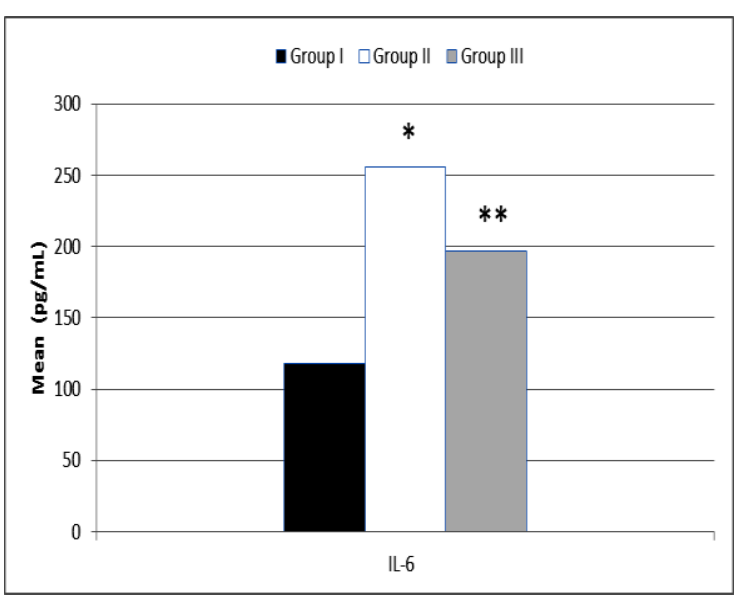

Fig. (2b): Effect of ghrelin on levels of IL-6 in plasma.* denotes significant differences group II vs group I, ** denotes significant differences group III vs group II 


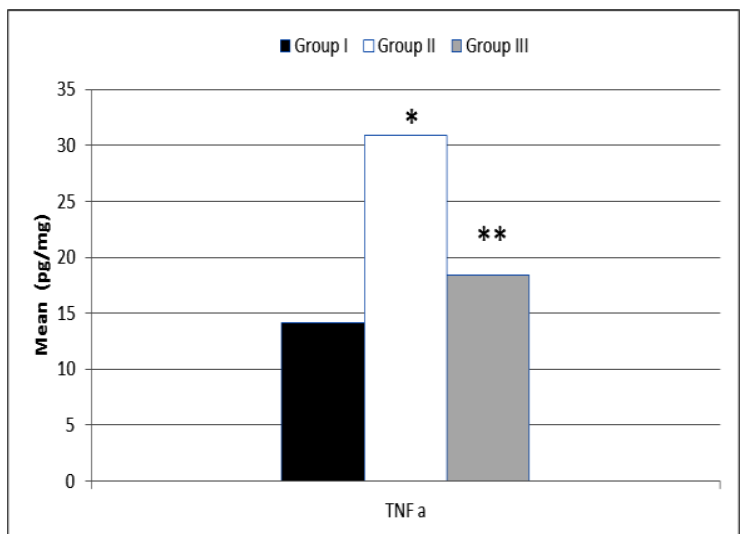

Fig.(3a): Effect of ghrelin on cardiac tissue TNF $(\mathrm{pg} / \mathrm{mg}$ protein) , * denotes significant differences group II vs. group I, ** denotes significant differences group III vs. GroupII

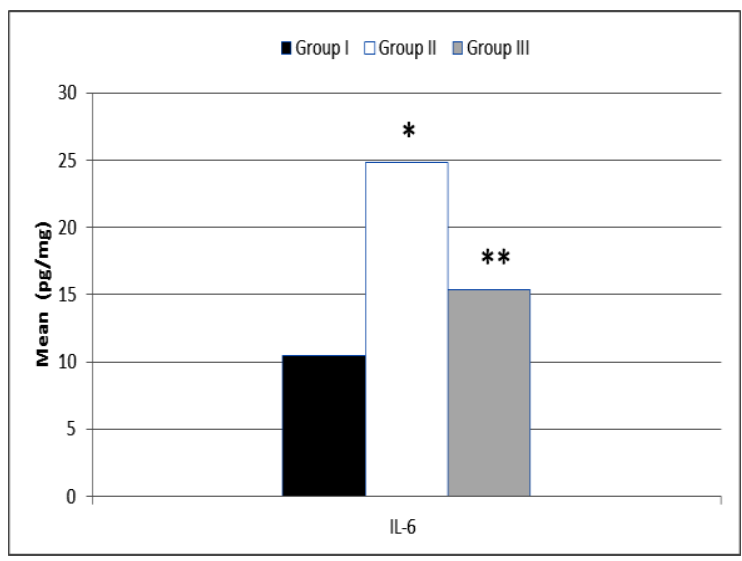

Fig. (3b): Effect of ghrelin on cardiac tissue IL-6 (pg/mg protein), * denotes significant differences group II vs. group I, ** denotes significant differences group III vs. group II

Levels of antioxidant enzymes (SOD, PON1 and lipid peroxidation products (MDA and GSH) in cardiac tissue unite in normal and experimental rats were expressed in figure 4 $(a, b)$ and figure $5(a, b)$. ISO-treated rats showed significant $(P<0.05)$ decrease in the activities of tissues SOD and PON1 enzyme activity and significant $(P<0.05)$ increase in heart tissues level of MDA and GSH when compared to control rats. Pretreatment with ghrelin significantly increased the activities of tissues SOD and PON1 and significantly decreased the heart tissues level of MDA and GSH when compared to ISO-treated rats.

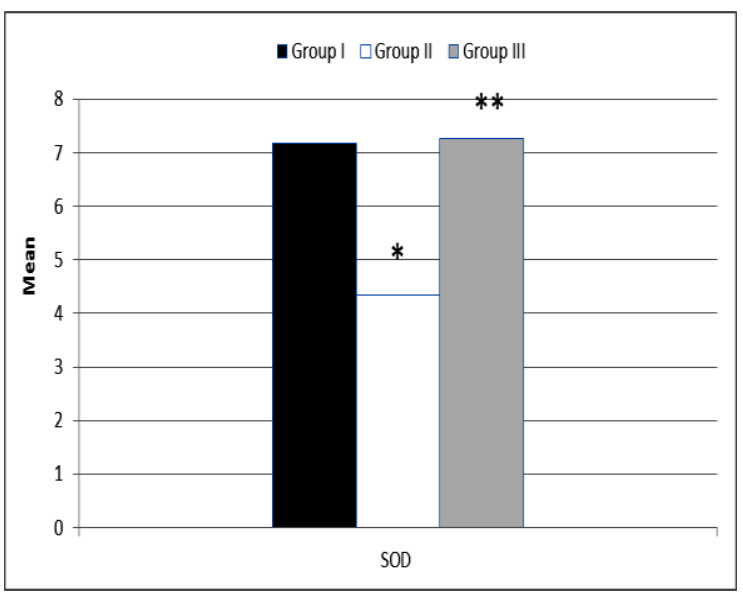

Fig. (4a): Effect of ghrelin on antioxidants enzymes (SOD) unite/mg protein in cardiac tissues.* denotes significant differences group II vs. group I, ** denotes significant differences GroupIII vs. group II

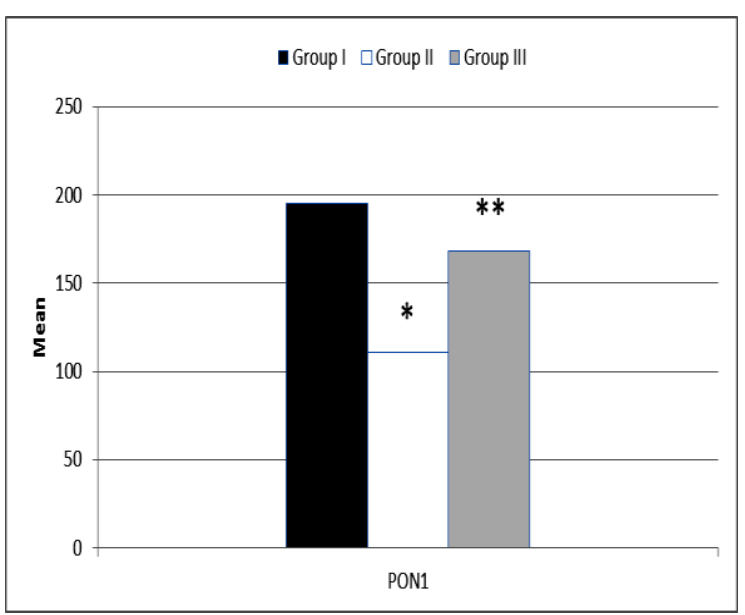

Fig. (4b): Effect of ghrelin on antioxidants enzymes (PON1) unite/mg protein in cardiac tissues.* denotes significant differences group II vs. group $\mathrm{I},{ }^{* *}$ denotes significant differences GroupIII vs. group II 


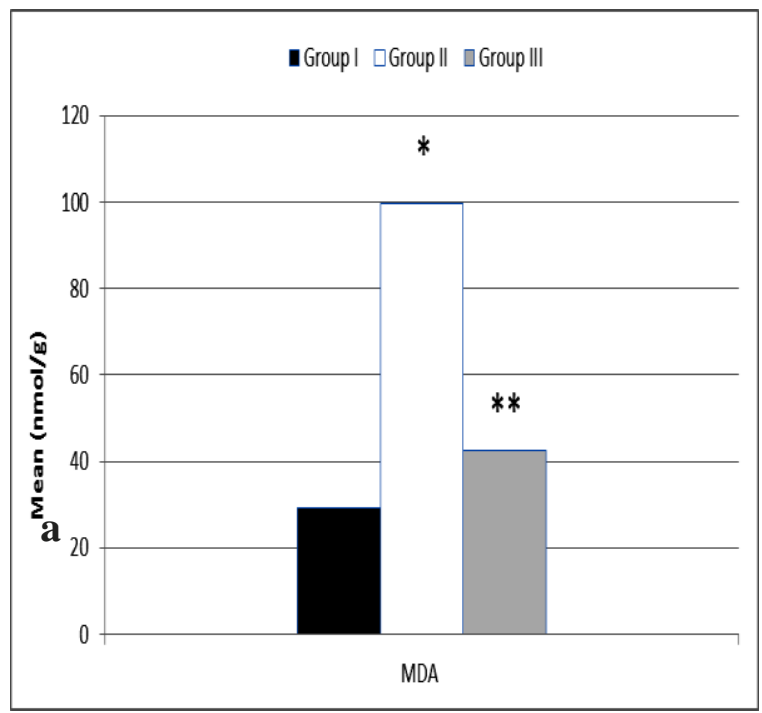

Fig. (5a): Effect of ghrelin onlipid peroxidation products (MDA) nmol/g in cardiac tissue unit. * significant differences group II vs. group I, ** significant differences group III vs. group II

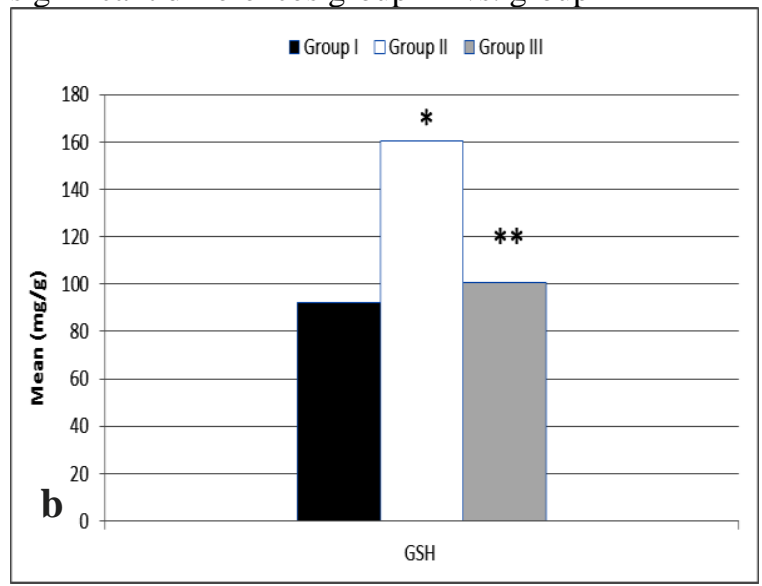

Fig. (5b): Effect of ghrelin on reduced glutathione $(\mathrm{GSH})(\mathrm{mg} / \mathrm{g})$ in cardiac tissue unit. * significant differences group II vs. group I

** significant differences group III vs. group II

Levels of lipid profile in serum of normal and experimental rats were expressed in figure (6). ISO-treated rats showed significant $(P<0.05)$ increase in the levels of serum cholesterol, triglycerides, LDLcholesterol and VLDL, and significant $(P<0.05)$ decrease in HDL-cholesterol compared to control rats. Pretreatment with ghrelin significantly decrease the levels of serum cholesterol, triglycerides, LDLcholesterol, VLDL and significantly increase the levels of HDL-cholesterol compared to ISO-treated rats.

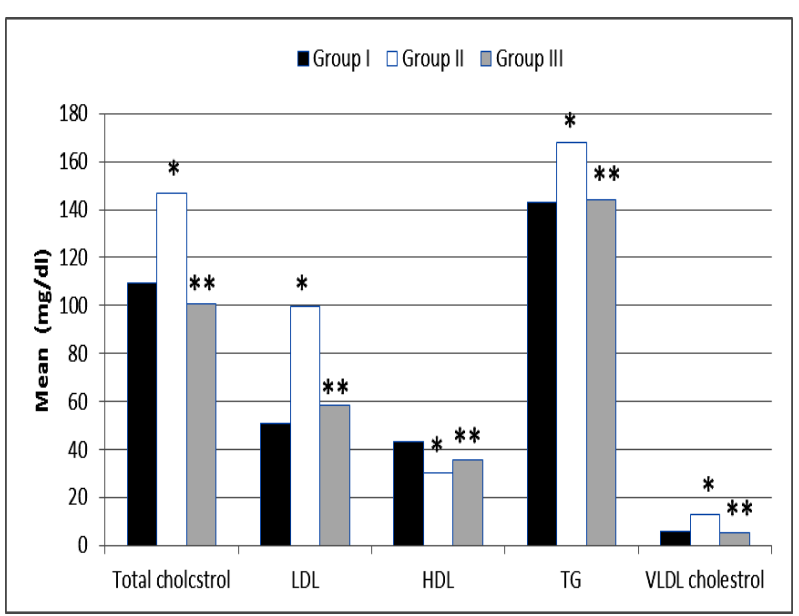

Fig. (6): Effect of ghrelin on levels of lipid profile in serum. * denotes significant differences group II vs. group I, ** denotes significant differences group III vs. group II

\section{DISCUSSION}

Myocardial infarction is a complex pathological process affecting all properties of cardiac muscle and it occurs when the blood supply to a part of the heart is interrupted, causing the death of heart tissue. $^{21} \quad$ ISO in large doses result in structural and functional changes in the heart leading to myocardial necrosis. This is evident from our study as high doses (>85 $\mathrm{mg} / \mathrm{kg}$ ) of Isoproterenol, a $\beta$-adrenergic agonist, has been found to cause severe stress in the myocardium resulting in infarct like necrosis of the heart muscle as evidenced by significant increase in cardiac enzymes markers (LDH, CK, and CK-MB) . These results are in line with previous 
reported results.$^{22,23}$ These cardio specific marker enzymes are released from the heart into the blood during acute myocardial necrosis due to deficiency of oxygen supply or glucose, and this result in disturbance of cell membrane integrity and results in the leakage of enzymes in the serum.$^{24}$

Also, excessive generation of ROS due to isoproterenol-induced oxidative stress directly injure the cell membrane result in leakage of cardiac enzymes in serum. ${ }^{25}$

Pre-treatment with ghrelin in isoproterenol treated animals reduce cardiac enzymes markers (LDH, CK, and CK-MB). The mechanisms by which ghrelin improved myocardial function and metabolism following ISO-damage could be mediated through the ability of ghrelin in interfering with ET-1 synthesis in ISO-induced myocardial injury. The peptide ET-1 was a potent and long-lasting vasoconstrictor and mitogen $^{26}$, and is considered as an important pathogenic factor of ISO-induced myocardial injury. ${ }^{27}$ Another mechanism by which ghrelin attenuated the myocardial injury was by inhibiting cardiomyocyte apoptosis in vitro by modulating extracellular signal-regulated kinase-1/2 and Akt serine kinases. ${ }^{28}$ Another mechanism explain the cardioprotective mechanism of ghrelin on isoproterenol-induced cardiac toxicity is the ability of ghrelin to attenuate endothelial dysfunction induced by ISO toxicity by increasing nitric oxide production using a signaling pathway that involves GHSR-1a, PI 3-kinase, Akt, and eNOS. ${ }^{6}$ Also, the cardiovascular protective effects of ghrelin may be mediated possibly through a direct effect on the cardiovascular cells, it prevents the increase in cardiac sympathetic nerve activity after MI, with improvement in energy balance. ${ }^{5}$ Moreover, it has been proved that ghrelin administration improved cardiac function and reduced myocardial injury induced by ischemia and reperfusion in the isolated rat heart, this effects were independent of growth hormone secretion. ${ }^{6}$

The role of oxidative stress in isoproterenol induced myocardial infarction in rats has been recognized. Isoproterenol induce myocardial infarction as a result of imbalance between formation of free radicals and anti-oxidant defense system. ${ }^{29,30}$ On the other meaning isoproterenol results in acute myocardial necrosis due to increased lipid peroxidation and decreased antioxidant enzymes, this is evidenced from our results by significant decrease in antioxidants enzymes (SOD and PON1) and significant increase in the level of lipid peroxidation products (MDA and GSH) in cardiac tissue which suggests the involvement of oxidative stress in ISO toxicity and these results are in line with the earlier reported studies. ${ }^{31}$

The mechanism by which ISO produce elevation in lipid peroxides with 
reduction in the activity of SOD and PON1

in cardiac tissues could be attributed to the accumulation of lipids in the heart causing damage to myocardial membranes ${ }^{32}$ or may be due to the increased generation of highly cytotoxic free radicals due to auto oxidation of catecholamine. ${ }^{33}$ ROS directly injure the cell membrane and cause cell death. ${ }^{34}$ However, ROS, also, stimulate signal transduction to elaborate inflammatory cytokines, for example, TNF- $\alpha$, interleukin (IL) $-1 \beta$, and -6 in the ischemic region and surrounding myocardium and these inflammatory cytokines, also, regulate cell survival and cell death in the chain reaction with ROS. ${ }^{(35)}$ Also, ROS can directly inhibit myocardial function in vivo and result in injury in cardiac myocytes and vascular cells. ${ }^{36}$

Our results are in agree with the previous studies 37,38 that reported that myocardial infarction is proven to be associated with inflammation with elevation of pro-inflammatory cytokines (such as TNF- $\alpha$ and IL-6). Pretreatment with ghrelin could exert anti-inflammatory effect in cardiac muscle as evidenced by significant decrease in level of inflammatory markers in the plasma, and cardiac tissues of ghrelin treated rats when compared to ISO alone treated rats. The mechanisms by which ghrelin exerts its anti-inflammatory effect and inhibits the expression of proinflammatory cytokines such as TNF- $\alpha$ and
IL-6 are variants. Ghrelin inhibits the production of proinflammatory cytokine, mononuclear cell binding, and nuclear factor-kappa B activation in human endothelial cells in vitro and endotoxininduced cytokine production in vivo. ${ }^{39}$ Dixi et al. reported that ghrelin suppresses proinflammatory factors, including TNF- $\alpha$, and reactive oxygen species generation human monocytes and $\mathrm{T}$ cells. ${ }^{40}$ The antiinflammatory effect of ghrelin which also include enhancing thymopoiesis and modulating phagocytosis may be direct or through GH production. ${ }^{41}$ Also, ghrelin exerts anti-oxidant effect this is evident from our results by significant increase in the levels of antioxidant enzymes (SOD and PON1) and significant decrease in the level of (GSH and MDA) in cardiac tissues of ghrelin treated rats when compared to ISO alone treated rats; these result are in agree with other studies which reported the antioxidant role of ghrelin in gastric tissues ${ }^{42}$ and in hepatic tissues. ${ }^{43}$ It has been proved that ghrelin enhanced mitochondrial enzyme activities in muscle, and increase muscle oxidative capacity. ${ }^{44}$

Dyslipidemia was considered as risk factor for cardiovascular diseases. ${ }^{45}$ An altered lipid metabolism can alter the cardiac function by changing the properties of cardiac cell membrane and these changes may contribute to the cell death. ${ }^{46} \mathrm{We}$ observed the increased levels of total 
cholesterol, LDL and VLDL and decreased level of HDL in the serum of ISO-induced rats. These changes in lipid levels might be due to enhanced lipid biosynthesis by cardiac cyclic adenosine monophosphate. ${ }^{47}$ Also, our study proved increase in cardiac tissues lipid peroxidation products levels in isopretrenol-treated group as evidenced by significant increase in cardiac tissues MDA which is the end product of lipid peroxidation products (thiobarbituric acid reactive substances) and significant decrease in PON1 which is antioxidant enzyme closely associated with high-density lipoproteins. It is a calcium-dependent esterase, which detoxifies lipid peroxides, and is widely distributed in many tissues, including the heart. ${ }^{48}$ Previous study demonstrates that isopretrenol intoxication in cardiac muscles tissue result in increased lipid peroxidation products with concomitant decrease in activities of lipoprotein lipase an enzyme concerned with triglycerides uptake from circulation. ${ }^{49}$ Also, it induces free radicals accumulation, which may cause cellular cholesterol accumulation, by increasing cholesterol biosynthesis and its esterification, decreasing cholesterol ester hydrolysis, and reducing cholesterol efflux and this may explain the dyslipidemic effect of ISO. ${ }^{50}$

Previous study demonstrates the effect of ghrelin on isoproterenol-induced lipoytic effect on adipocytes in vitro, where ghrelin significantly reduced the release of glycerol in rat adipocytes which were stimulated by isoproterenol. ${ }^{51}$ Also, it has been demonstrated that ghrelin plays a significant role in the regulation of lipid profiles and body composition and a positive correlation between ghrelin and high-density lipoprotein (HDL) cholesterol concentration has also been observed. ${ }^{52,53}$ The antilipolytic effect of ghrelin is very similar to that of insulin, which inhibits lipolytic activity in fat cells ${ }^{54}$; it decreases intracellular cAMP via activation of adipocyte cAMP phosphodiesterase; this reduction leads to the inactivation of not only the cAMPdependent protein kinase but also dephosphorylation of hormone-sensitive lipase. $^{55}$

Ghrelin is associated with changes in energy homeostasis favoring lipogenesis in vivo due to increase the expression of PPAR- $\gamma 2$ gene that is important for adipogenesis. ${ }^{56}$ In addition, evidence has demonstrated that central administration of ghrelin stimulate the lipogenic program in the white adipose tissue, via the sympathetic nervous system. ${ }^{57}$

\section{CONCLUSIONS}

The present study demonstrates that ghrelin may be considered as promising new therapy for MI through its antioxidant, antinflammatory and antihyperlipidaemic effects which exert cardioprotective effect against acute myocardial infarction. 


\section{REFERENCES}

1. 1.Yogeeta SK, Gnanapragasam A, Kumar SS, Subhashini R, Sathivel A, Devaki T: Synergistic interactions of ferulic acid with ascorbic acid: its cardioprotective role during isoproterenol induced myocardial infarction in rats. Mol Cell Biochem. 283:139-46, 2006.

2. 2.Wu Y, Yin X, Wijaya C, Huang MH, McConnell BK: Acute myocardial infarction in rats. J Vis Exp. 16:48-50, 2011.

3. 3.Yeap XY, Dehn S, Adelman J, Lipsitz

J, Thorp EB: Quantitation of acute necrosis after experimental myocardial infarction. Methods Mol Biol 1004:11533, 2013.

4. Chanoine JP: Ghrelin in growth and development. Horm Res. 63:129-38, 2005

5. Kishimoto I, Tokudome T, Hosoda H, Miyazato M, Kangawa K: Ghrelin and cardiovascular diseases. J Cardiol. 59:8$13,2012$.

6. 6.Tesauro M, Schinzari F, Caramanti M, Lauro R, Cardillo C: Cardiovascular and metabolic effects of ghrelin. Curr Diabetes Rev. 6:228-35, 2010.

7. Punithavathi VR, Prince PS: Combined effect of quercetin and alpha tocopherol on lipids and glycoprotein components in isoproterenol induced wistar rats. Chem Biol Interact. 181:322-7, 2009.

8. Rosalki SB: An improved procedure for serum creatine phosphokinase determination. J Lab Clin Med. 69:696705, 1967.

9. Grande P, Christiansen C, Naestoft J: Creatine kinase isoenzyme MB assay by electrophoresis. Scand J Clin Lab Invest. 39: 607-12, 1979.

10. Henry RJ, Chiamori N, Goiub OJ, Berkman S: $\quad$ Revised spectrophotometric methods for the determination of glutamic-oxalacetic transaminase, glutamic-pyruvic transaminase and lactic acid dehydrogenase. Am J Clin Pathol. 34:381-98, 1960.

11. Deeg R, Ziegenohrm J: Kinetic enzymatic method for automated determination of total cholesterol in serum. Clin Chem. 29:1798-1802, 1983.

12. Fossati P, Prencipe L: Serum triglycerides determined colourmetrically with an enzyme that produces hydrogen peroxide. Clin Chem. 28:2077-80, 1982.

13. Friede WT, Levy RT, Fredrickson DF: Estimation of the concentration of Low Density Lipoprotein Cholesterol in plasma without use of the preparation ultra centrifuge. Ann Chem. 18:499, 1972. 
14. Burestin M, Selvenick HR, Morfin R: Rapid method for the isolation of lipoproteins from human serum by precipitation with polyanions. Lipid Res. 11:583, 1970.

\section{Lowry OH, Rosebrough NJ, Farr AL,} Randall RJ: Protein measurement with the folin phenol reagent. J Biol Chem. 193:265-75, 1951.

16. Sinha AK: Colorimetric assay of catalase. Anal Biochem. 47:389-94, 1972.

17. Ohkawa H, Ohishi N, Yagi K: Assay for lipid peroxides in animal tissues by thiobarbituric acid reaction. Anal Bio Chem. 95:351-8, 1979.

18. Sedlak J, Lindsay RH: Estimation of total, protein bound and nonprotein sulfhydryl groups in tissue with Ellman's reagent. Anal Biochem. 25:192-205, 1968.

19. Kakkar P, Das B, Viswanathan PN: A modified spectrophotometric assay of superoxide dismutase. Indian J Biochem Biophys. 21:130-2, 1984.

20. McElveen J, Mackness MI, Colley CM, Peard T, Warner S, Walker CH: Distribution of Paraoxon Hydrolytic Activity in the Serum of Patients after Myocardial Infarction. Clin Chem. 32:671, 1986.

\section{Rajadurai M, StanelyMainzen Prince} P: Preventive effect of naringin on cardiac markers, electrocardiographic patterns and lysosomal hydrolases in normal and isoproterenolinduced myocardial infarction in Wistar rats. Toxicology 230:88-178, 2007

22. StanelyMainzen Prince P, Roy AJ: pCoumaric acid attenuates apoptosis in isoproterenolinduced myocardial infarcted rats by inhibiting oxidative stress. Int $\mathrm{J}$ Cardiol. 168:3259-66, 2013.

23. Prince PS: A biochemical, electrocardiographic, electrophoretic, histopathological and in vitro study on the protective effects of epicatechin in isoproterenolinduced myocardial infarcted rats. Eur J Pharmacol. 671:95-101, 2011.

\section{SabeenaFarvin KH, Anandan} R, Kumar SH, Shiny KS, Sankar TV, Thankappan TK: Effect of squalene on tissue defense system in isoproterenol-induced myocardial infarction in rats. Pharmacol Res, 50:231-6, 2004.

25. Shi M, He W, Liu Y, Li X, Yang S, Xu Q: Protective effect of total phenylethanoid glycosides from Monochasma savatieri. Phyto Medicine 20:1251-5, 2013.

\section{Xu JT, Tang CS, Hu DY, Pang YZ:}

Effect of endothelin-endothelinreceptor on thrombin-induced vascular smooth muscle cell proliferation. Chin J Microcirc. 12:38-9, 2002. 
27. Chang L, Zhao J, Li GZ, Geng B, Pan CS, Qi YF, Tang CS: Ghrelin protects myocardium from isoproterenol-induced injury in rats. Acta Pharmacol Sin. 25:1131-37, 2004.

28. Bodart V, Febbraio M, Demers A, McNicoll N, Pohankova P, Perreault A: CD36 mediates the cardiovascular action of growth hormone-releasing peptides in the heart. Circ Res.90:844-9, 2002.

29. Rathore N, John S, Kale M, Bhatnagar D: Lipid peroxidation and antioxidant enzymes in isoproterenol induced oxidative stress in rat tissues. Pharmacol Res. 38:297-303, 1998

30. Devika PT, Prince PS: Protective effect of epigallocatechin-gallate (EGCG) on lipid peroxide metabolism in isoproterenol induced myocardial infarction in male Wistar rats: a histopathological study. Biomed Pharmacother. 62:701-8, 2008.

\section{Saleem TS, Lokanath N, Prasanthi} A, Madhavi M, Mallika G, Vishnu MN: Aqueous extract of Saussurealappa root ameliorate oxidative myocardial injury induced by isoproterenol in rats. $\mathrm{J}$ Adv Pharm Technol Res. 4:94-100, 2013.

32. 32.Yang RL, Shi YH, Hao G, Li W, Le GW: Increasing oxidative stress with progressive hyperlipidemia in human:
Relation between malondialdehyde and atherogenic index. J Clin Bio Biochem Nutr. 43: 154-8, 2008.

\section{Rajadurai M, StanelyMainzen Prince}

P: Preventive effect of naringin on cardiac markers, electrocardiographic patterns and lysosomal hydrolases in normal and isoproterenol-induced myocardial infarction in Wistar rats. Toxicology 230:178-88, 2007.

34. Hori M, Nishida K: Oxidative stress and left ventricular remodelling after myocardial infarction. Cardiov Res. 81(3):457-464, 2009.

35. Fantinelli JC, González Arbeláez LF, Pérez Núñez IA, Mosca SM: Protective effects of N-(2mercaptopropionyl)-glycine against ischemia-reperfusion injury in hypertrophied hearts. Exper Molec Path. 94:277-84, 2013.

36. Scarabelli TM, Knight R, Stephanou A, Townsend P, Chen-Scarabelli C, Lawrence K, Gottlieb R, Latchman D, Narula J: Clinical implications of apoptosis in ischemic myocardium. Curr Prob Cardiol. 31:181-264, 2006.

37. Rajappa M, Sen SK, Sharma A: Role of pro-/anti-inflammatory cytokines and their correlation with established risk factors in South Indians with coronary artery disease .Angiology 60: 419, 2009. 
38. Danesh J, Kaptoge S, Mann AG, Sarwar N, Wood A, Angleman SB, Wensley F, Higgins JP, Lennon L, Eiriksdottir G, RumleyA,Whincup PH, Lowe GD, Gudnason V: Longterm interleukin-6 levels and subsequent risk of coronary heart disease: two new prospective studies and a systematic review. Plos Med 2008; 75:8.

39. Li WG, Gavrila D, Liu X, et al: Ghrelin inhibits proinflammatory responses and nuclear factor-kappaB activation in human endothelial cells. Circulation 109:2221-26, 2004.

40. Dixit VD, Schaffer EM, Pyle RS: Ghrelin inhibits leptin- and activationinduced proinflammatory cytokine expression by human monocytes and $\mathrm{T}$ cells. J Clin Invest. 114:57-66, 2004.

41. Hattori N: Expression, regulation and biological actions of growth hormone (GH) and ghrelin in the immune system. Growth Horm IGF Res. 19:18797, 2009

42. Coskun ZM, Sacan O, Karatug A, Turk N, Yanardag R, Bolkent S, Bolkent S: Regulation of oxidative stress and somatostatin, cholecystokinin, apelin gene expressions by ghrelin in stomach of newborn diabetic rats. Acta Histochem. 115:740-7, 2013.

43. Cetin E, Kanbur M, Cetin N, Eraslan G, Atasever A: Hepatoprotective effect of ghrelin on carbon tetrachlorideinduced acute liver injury in rats. Regul Pept. 171:1-5, 2011.

\section{Barazzoni R, Zhu X, Deboer M, Datta} R, Culler MD: Combined effects of ghrelin and higher food intake enhance skeletal muscle mitochondrial oxidative capacity and AKT phosphorylation in rats with chronic kidney disease. Kidney Int. 77:23-8, 2010.

45. Cziraky MJ, Watson KE, Talbert RL: Targeting low HDL-cholesterol to decrease residual cardiovascular risk in the managed care setting. J Manag Care Pharm. 14 (8 Suppl): S3-28, 2008.

46. 46. Priscilla DH, Prince PS: Cardioprotective effect of gallic acid on cardiac troponin-T, cardiac marker enzymes, lipid peroxidation products and antioxidants in experimentally induced myocardial infarction in Wistar rats. Chem Biol Interact. 179:118-24, 2009 .

\section{Senthil S, Sridevi M, Pugalendi KV:} Cardioprotective effect of oleanolic acid on isoproterenol-induced myocardial ischemia in rats. Toxicol Pathol. 35:41823, 2007.

48. Sentí M, Tomás M, Fitó M, Weinbrenner T, Covas M, Sala J, Masiá R, Marrugat J: Antioxidant paraoxonase 1 activity in the metabolic syndrome. J Clin Endocrinol Metab. 88:5422-26, 2003. 
49. Yogeeta SK, Hanumantra RB, Gnanapragasam A, Senthilkumar S, Subhashini R, Devaki T: Attenuation of abnormalities in the lipid metabolism during experimental myocardial infarction induced by isoproterenol in rats: beneficial effect of ferulic acid and ascorbic acid. Basic Clin Pharmacol Toxicol. 98:467-72, 2006.

50. Spiteller G: The relation of lipid peroxidation processes with atherogenesis: a new theory on atherogenesis. Mol Nutr Mol Res. 49: 999-1013, 2005.

51. Muccioli G, Pons N, Ghè C, Catapano F, Granata R, Ghigo E: Ghrelin and des-acyl ghrelin both inhibit isoproterenol-induced lipolysis in rat adipocytes via a non-type 1a growth hormone secretagogue receptor. Eur J Pharmacol. 498:27-35, 2004.

52. Fagerberg B, Hultén LM, Hulthe J: Plasma ghrelin, body fat, insulin resistance, and smoking in clinically healthy men: the atherosclerosis and insulin resistance study. Metabolism 52:1460-63, 2003.

\section{Langenberg C, Bergstrom J, Laughlin} GA, Barrett-Connor E: Ghrelin and the metabolic syndrome in older adults. J Clin Endocrin Met. 90:6448$53,2005$.

\section{Szkudelska K, Nogowski L,}

Szkudelski T: Resveratrol, a naturally occurring diphenolic compound, affects lipogenesis, lipolysis and the antilipolytic action of insulin in isolated rat adipocytes. $\mathbf{J}$ Steriod Biochem Mol Bio. 113:17-24, 2009.

55. Chakrabarti P, Kandror KV: Adipose triglyceride lipase: a new target in the regulation of lipolysis by insulin. Curr Diabetes Rev. 7: 270-7, 2011.

56. Cao C, Chen Y, Wang W, Liu Y, Liu G: Ghrelin inhibits insulin resistance induced by glucotoxicity and lipotoxicity in cardiomyocyte. Peptides 32:209-15, 2011.

57. Theander-Carrillo $\mathbf{C}$, Wiedmer $\mathbf{P}$, Cettour-Rose P, Nogueiras R, PerezTilve D, Pfluger P, Castaneda TR, Muzzin P, Schürmann A, Szanto I, Tschöp MH, Rohner-Jeanrenaud F: Ghrelin action in the brain controls adipocyte metabolism. J Clin Invest. 116: 1983-93, 2006. 